\title{
A Possible Mechanism of Cisplatin-Induced Tumor Necrosis Factor (TNF)- $\alpha$ Production in Murine Macrophages
}

\author{
Seikou Kim, Kouichi Yamamoto*, Yusuke Nakamura, Yuichi Otoyo, Atsushi Yamatodani \\ Laboratory of Pharmacology, Department of Medical Science and Technology, Division of Health Science, Graduate School of \\ Medicine, Osaka University, Osaka, Japan. \\ Email: ${ }^{*}$ kouichi@sahs.med.osaka-u.ac.jp
}

Received January $22^{\text {nd }}, 2013$; revised February $23^{\text {rd }}, 2013$; accepted March $28^{\text {th }}, 2013$

Copyright (C) 2013 Seikou Kim et al. This is an open access article distributed under the Creative Commons Attribution License, which permits unrestricted use, distribution, and reproduction in any medium, provided the original work is properly cited.

\begin{abstract}
Cisplatin has been used for the treatment of various solid cancers or sarcomas; however, it can induce severe adverse effects. Among these adverse effects, nephrotoxicity, which has the potential to be a dose-limiting factor of this agent, develops due to the secretion of tumor necrosis factor- $\alpha$ (TNF- $\alpha)$ from macrophages; however, the precise mechanisms are still unclear. To elucidate possible mechanisms, we investigated the involvement of mitogen-activated protein kinases (MAPK) and reactive oxygen species (ROS) in cisplatin-induced TNF- $\alpha$ mRNA expression and protein production in the mouse macrophage-like cell line, RAW 264. Cisplatin $(1 \mu \mathrm{M})$ significantly increased TNF- $\alpha$ mRNA expression and protein production. Extracellular-regulated kinase (ERK) and p38 MAPK, but not c-Jun N-terminal kinase (JNK), phosphorylation increased in response to cisplatin. Although an ERK inhibitor (PD98059) suppressed both cisplatin-induced TNF- $\alpha$ mRNA expression and its protein production, a p38 MAPK inhibitor (SB203580) decreased TNF- $\alpha$ protein production only. A JNK inhibitor (SP600125) had no effect on cisplatin-induced TNF- $\alpha$ mRNA expression. Furthermore, a scavenger of ROS, N,N'-dimethylthiourea, suppressed both ERK activation and TNF- $\alpha$ mRNA expression. These results suggest that the phosphorylation of ERK by ROS is involved in cisplatin-induced TNF- $\alpha$ mRNA expression and that the signaling pathway of $\mathrm{p} 38$ MAPK is related to TNF- $\alpha$ protein production.
\end{abstract}

Keywords: Cisplatin; Reactive Oxygen Species (ROS); Macrophage; RAW264; MAPK; TNF- $\alpha$

\section{Introduction}

Cisplatin has been used for the treatment of various solid cancers or sarcomas; however, it can cause severe adverse effects including renal and cochlear injuries $[1,2]$. Nephrotoxicity, which is caused by the accumulation of cisplatin in the proximal tubule, has the potential to be a dose-limiting factor of this therapy. Previous studies reported that proximal tubular injury was caused due to increases in macrophage infiltration by cisplatin $[3,4]$ and subsequent overproduction of the pro-inflammatory cytokine, tumor necrosis factor (TNF)- $\alpha$, in tubule cells [5-7]. Thus, inhibiting the production and secretion of TNF- $\alpha$ in macrophages may be advantageous in reducing cisplatin-induced renal injury. The production of proinflammatory cytokines including TNF- $\alpha$ is mediated by

\footnotetext{
"Corresponding author.
}

the activation of mitogen-activated protein kinase (MAPK) family members [6]. MAPK pathways are cascades of serine/threonine kinases comprising three families members; extracellular signal-regulated kinase (ERK), p38 MAPK, and c-Jun N-terminal kinase (JNK), that are activated by chemical stresses and reactive oxygen species (ROS) [8-10]. The ERK signaling module is involved in cell growth, proliferation, and survival. On the other hand, the activation of p38 MAPK and JNK generally results in inflammation $[8,9,11]$. Ramesh et al. reported that cisplatin induced TNF- $\alpha$ mRNA expression via activation of the p38 MAPK pathway in renal proximal tubular cells [12]. However, the possible mechanism of cisplatin-induced TNF- $\alpha$ expression in macrophages has not been fully elucidated. In this study, we investigated the mechanism of cisplatin-induced TNF- $\alpha$ production in macrophages, with a focus on MAPK pathways, using the mouse macrophage-like cell line, RAW 264. 


\section{Materials and Methods}

\subsection{Cells Cultures}

Murine macrophage-like cell line RAW 264 cells (No. RCB0535) was provided by the RIKEN RBC through the National Bio-Resource Project of the MEXT, Japan. Cells were cultured in Minimum Essential Medium Eagle (Sigma-Aldrich) supplemented with $10 \%$ (v/v) heat-incubated fetal bovine serum (Biowest, Nuaille, France), $0.1 \mathrm{mM}$ non-essential amino acids (Nacalai Tesque, Kyoto, Japan), $5000 \mathrm{U} / \mathrm{ml}$ penicillin, and $5000 \mu \mathrm{g} / \mathrm{ml}$ streptomycin (Nacalai Tesque) in a humidified atmosphere of $5 \%$ $\mathrm{CO}_{2}$ at $37^{\circ} \mathrm{C}$.

\subsection{Chemicals}

Stock solutions of cis-Diammineplatinum (II) dichloride (cisplatin) and N,N'-dimethylthiourea (DMTU), which were obtained from Sigma-Aldrich (St. Louis, MO, USA), were prepared in Minimum Essential Medium Eagle (Sigma-Aldrich). Inhibitors of ERK (PD98059), p38 MAPK (SB203580), and JNK (SP600125) were purchased from Cayman Chemical (Ann Arbor, MI, USA), Jena Bioscience (Jena, Germany), and Enzo Life Sciences (Farmingdale, NY, USA), respectively. Stock solutions were prepared in dimethylsulfoxide (DMSO: SigmaAldrich) and were added to cell cultures at a concentration of $1 \mu \mathrm{M}$. The final volume of DMSO in each well was $0.01 \%(\mathrm{v} / \mathrm{v})$.

\subsection{TNF- $\alpha$ mRNA Assay}

RAW264 cells were seeded in 12 well plates $\left(1 \times 10^{6}\right.$ cells/well) and incubated for $24 \mathrm{~h}$. Cells were pretreated with the three different types of MAPK inhibitors $(0.1$ $10 \mu \mathrm{M})$ or DMTU $(100 \mu \mathrm{M})$ for $0.5 \mathrm{~h}$, followed by stimulation with cisplatin $(1 \mu \mathrm{M})$ for $24 \mathrm{~h}$. After incubation, the expression of TNF- $\alpha$ mRNA was analyzed by reverse transcription polymerase chain reaction (RTPCR). Total RNA was extracted using an RNA extraction kit (Viogene, Taipei, Taiwan) according to the manufacturer's instructions. RNA was converted into a firststrand complementary DNA (cDNA) by ReverTra Ace (TOYOBO, Osaka, Japan). cDNA was then used as a template for RT-PCR with TNF- $\alpha$ and glyceraldehyde 3-phosphate dehydrogenase (GAPDH) specific primers in a thermal cycler (PC-320, ASTEC, Fukuoka, Japan). The specific primers (Invitrogen, Carlsbad, CA, USA) used in this study are listed below: TNF- $\alpha, 5$ '-GGG TGT GAA CCA CGA GAA AT-3' and 5'-TTA CTC CTT GGA GGC CAT GT-3'; GAPDH,5'-GGG TGT GAA CCA CGA GAA AT-3' and 5'-TTA CTC CTT GGA GGC CAT GT-3'. The PCR program was $30 \mathrm{sec}, 95^{\circ} \mathrm{C}$, followed by 26 cycles of denaturation, $30 \mathrm{sec}, 95^{\circ} \mathrm{C}$; annealing was $30 \mathrm{sec}, 50^{\circ} \mathrm{C}$; elongation, 1 minute, $72^{\circ} \mathrm{C}$, followed by 5 minutes, $72^{\circ} \mathrm{C}$. PCR products (TNF- $\alpha$ : 346 bp, GAPDH: $610 \mathrm{bp}$ ) were separated on $1.8 \%$ agarose gels (Nacalai Tesque) and stained with a 1/10,000 dilution of SYBR Safe DNA gel stain (Invitrogen). Gels were captured with E-graph (AE-900, ATTO, Tokyo, Japan) and band densities were analyzed for quantification using the CS Analyzer ver3.0 (ATTO). The expression levels of TNF- $\alpha$ were normalized to corresponding GAPDH mRNA levels.

\subsection{MAPK Phosphorylation Assay}

Cells $\left(6 \times 10^{4}\right.$ cells/well $)$ were pretreated with or without DMTU $(100 \mu \mathrm{M})$ for $0.5 \mathrm{~h}$, followed by stimulation with cisplatin $(1 \mu \mathrm{M})$ for $24 \mathrm{~h}$. ERK, p38 MAPK and JNK phosphorylation levels were determined using an ELISA assay kit (Cell-Based ERK1/2 (activated) ELISA Sampler Kit, RayBiotech, Norcross, GA, USA) according to the manufacturer's instructions. The absorbance of each well was read at $450 \mathrm{~nm}$ using the microplate reader (Model 680, Bio-Rad, Hercules, CA, USA).

\subsection{TNF- $\alpha$ Protein Assay}

Cells were harvested in 12 well plates $\left(1 \times 10^{5}\right.$ cells/well $)$ and treated with PD98059 $(1 \mu \mathrm{M})$ or SB203580 $(1 \mu \mathrm{M})$ between $0.5 \mathrm{~h}$ and $72 \mathrm{~h}$ after cisplatin $(1 \mu \mathrm{M})$ stimulation. $\mathrm{TNF}-\alpha$ protein levels in the supernatant were then determined using an ELISA assay kit (Mouse TNF- $\alpha$ Quantikine ELISA Kit, R\&D Systems, Minneapolis, MN, USA) according to the manufacturer's protocol. The absorbance of each well was read at $450 \mathrm{~nm}$ using a microplate reader.

\subsection{Cell Viability}

Cells were cultured in varying concentrations of cisplatin between $0.01 \mu \mathrm{M}$ and $10 \mu \mathrm{M}$ for $24 \mathrm{~h}$ and cytotoxicity was evaluated by trypan blue staining (Gibco, Grand Island, NY, USA).

\subsection{Statistical Analysis}

Data were expressed as mean \pm S.E.M. and analyzed statistically using a one-way analysis of variance followed by the Dunnett's Multiple Comparison Test. Values of $p<0.05$ were determined to be significant.

\section{Results}

\subsection{Involvement of the MAPK Pathway on Cisplatin-Induced TNF- $\alpha$ mRNA Expression and Protein Production}

Cisplatin dose-dependently increased TNF- $\alpha$ mRNA expression. A marked increase was observed with the administration of $1 \mu \mathrm{M}$ cisplatin (Figure 1(A)). We ob- 
served no significant suppression in cell viability when cells were stimulated with cisplatin at a concentration of $1 \mu \mathrm{M}$ (data not shown). PD98059, SB203580, or SP600125 alone did not affect TNF- $\alpha$ mRNA expression in RAW264 cells. PD98059 at a dose of $1 \mu \mathrm{M}$ and $10 \mu \mathrm{M}$ significantly inhibited cisplatin-induced TNF- $\alpha$ mRNA expression, but any dose of SB203580 and SP600125 did not inhibit cisplatin induced TNF- $\alpha$ mRNA expression (Figures 1(B)-(D)). As shown in Figure 2, cisplatin significantly increased ERK and p38 MAPK to 1.4 and 1.7-fold higher than that of controls, respectively; however, a similar response was not observed for JNK phosphorylation. Pretreatment with PD98059 and SB203580 significantly suppressed cisplatin-induced TNF- $\alpha$ protein production and levels in PD98059-treated cells and returned them to control levels (control: $142.6 \pm 2.0 \mathrm{pg} / \mathrm{ml}$, cisplatin: $231.7 \pm 8.5 \mathrm{pg} / \mathrm{ml}$, cisplatin + PD98059: $143.3 \pm$ $10.9 \mathrm{pg} / \mathrm{ml}$, cisplatin + SB203580: $177.4 \pm 17.9 \mathrm{pg} / \mathrm{ml}$ ) (Figure 3).

\subsection{The Effect of a Radical Scavenger on TNF- $\alpha$ mRNA Expression and MAPK Phosphorylation}

Although DMTU alone did not affect TNF- $\alpha$ mRNA expression, it significantly reduced cisplatin-induced TNF- $\alpha$ mRNA expression to the level of controls (Figure 4(A)). Furthermore, DMTU significantly decreased cisplatin-induced phosphorylation of ERK, but not that of p38 MAPK (Figure 4(B)).

\section{Discussion}

In this study, we demonstrated that cisplatin significantly increased TNF- $\alpha$ mRNA expression (Figure 1(A)). Using specific inhibitors of MAP kinase family members, we found that the transcription of TNF- $\alpha$ mRNA is dependent on ERK, but not p38 MAPK or JNK (Figures 1(B)-(D)). Several studies have shown that p38 MAPK and JNK are involved in inflammation and that their activation results in the production of inflammatory cytokines including TNF- $\alpha[9,13]$. Our results suggest that p38 MAPK and JNK did not suppress the expression of cisplatin-induced TNF- $\alpha$ mRNA (Figures 1(C) and (D)). Previous reports have revealed that p38 MAPK is involved in the nucleocytoplasmic transport of TNF- $\alpha$ mRNA [14] and its phosphorylation causes TNF- $\alpha$ mRNA stabilization; thus, this activation is associated with an increase in the production of TNF- $\alpha$ protein.

We actually found that cisplatin induced p38 MAPK phosphorylation under the condition of increased TNF- $\alpha$ mRNA expression (Figure 2), and its inhibitor, SB203580, suppressed cisplatin-induced TNF- $\alpha$ protein production without affecting TNF- $\alpha$ mRNA expression (Figure 3). These findings suggested that p38 MAPK pathways are
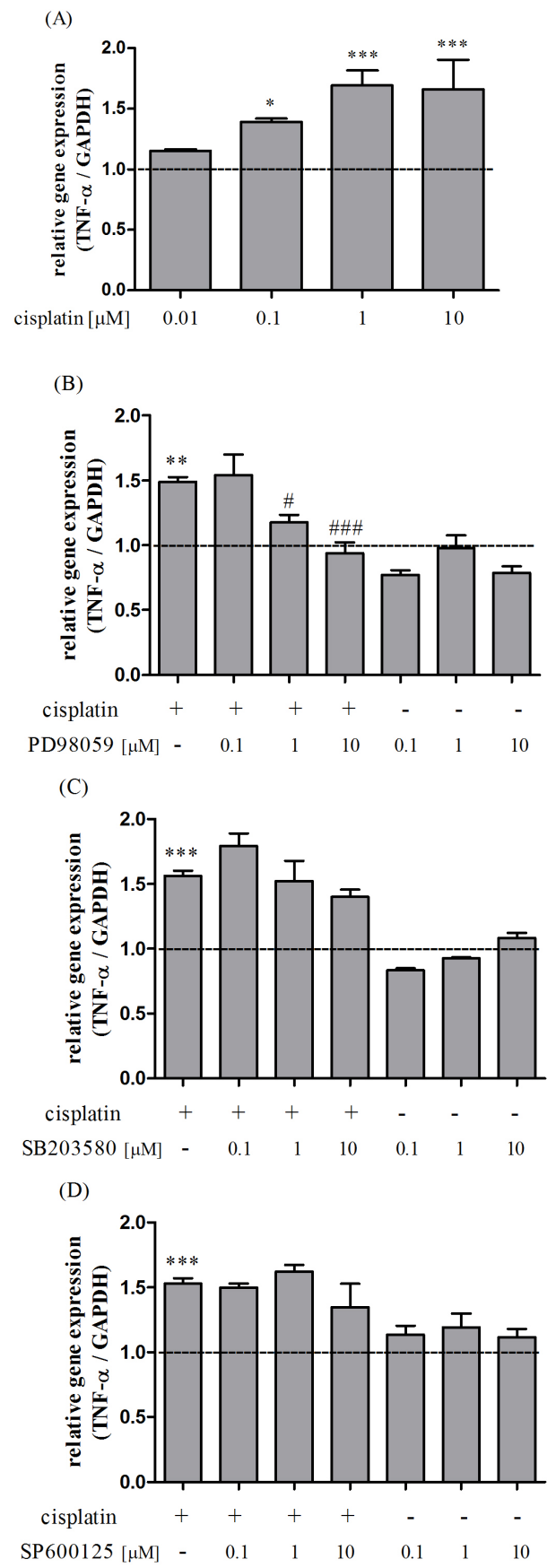

Figure 1. The effects of MAPK inhibitors on cisplatin-induced TNF- $\alpha$ mRNA expression. RAW264 cells were treated with $0.01-10 \mu \mathrm{M}$ cisplatin or vehicle for $24 \mathrm{~h}(\mathrm{~A})$ and were treated with the ERK inhibitor; PD98059 (0.1 - $10 \mu \mathrm{M})(\mathrm{B})$, p38 MAPK inhibitor; SB203580 (0.1 - $10 \mu \mathrm{M})(\mathrm{C})$, and JNK inhibitor; SP600125 (0.1 - $10 \mu \mathrm{M})$ (D) between $0.5 \mathrm{~h}$ before and after cisplatin $(1 \mu \mathrm{M})$ or with vehicle stimulation. TNF$\alpha$ mRNA expression was analyzed by RT-PCR. Expression levels were normalized to the corresponding GAPDH mRNA levels. The mean value of the control group was set

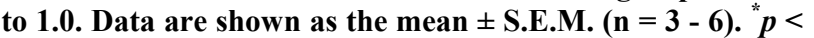
$0.05,{ }^{* *} p<0.01$, and ${ }^{* * *} p<0.001$ significantly different from the control group. ${ }^{\#} p<0.05$ and ${ }^{\# \#} p<0.001$ significantly different from the cisplatin group. 


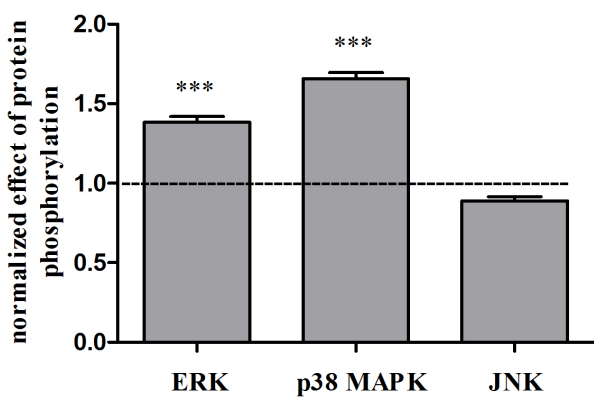

Figure 2. The effects of cisplatin on MAPK pathway activation. ERK, p38 MAPK, and JNK phosphorylation in cells treated with $1 \mu \mathrm{M}$ cisplatin or vehicle for $24 \mathrm{~h}$ were analyzed by an ELISA assay kit. Phosphorylation in RAW264 cells treated with a respective inhibitor alone was defined as the value of control levels. Data are shown as the mean \pm S.E.M. $(n=3-4) .{ }^{* * *} p<0.001$ significantly different from the control group.

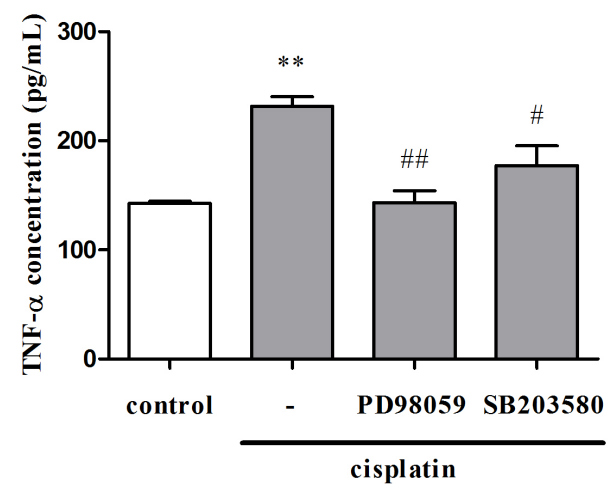

Figure 3. The effects of MAPK inhibitors on cisplatin-induced TNF- $\alpha$ production. RAW264 cells were treated with $1 \mu \mathrm{M}$ PD98059 and $1 \mu \mathrm{M}$ SB203580 between $0.5 \mathrm{~h}$ before and $72 \mathrm{~h}$ after $1 \mu \mathrm{M}$ cisplatin stimulation. TNF- $\alpha$ levels in the supernatant were determined using an ELISA assay kit. Data are shown as the mean \pm S.E.M. $(\mathrm{n}=3) .{ }^{* *} p<0.01$ significantly different from the control group. ${ }^{\#} p<0.05$ and ${ }^{\#} p<0.01$ significantly different from the cisplatin group.

also closely related to the process of cisplatin-induced TNF- $\alpha$ protein synthesis rather than its mRNA expression.

On the other hand, although Swantek et al. reported that the JNK pathway mainly regulates the translation of TNF- $\alpha$ mRNA [15], we confirmed that cisplatin was not involved in the phosphorylation of JNK and SP600125 did not affect cisplatin-induced expression of TNF- $\alpha$ mRNA in RAW264 cells $24 \mathrm{~h}$ after cisplatin treatment. Sánchez-Pérez et al. reported that cisplatin induced transient activation of the JNK pathway within a few hours via the regulation of its upstream-kinase MEKK1 [16,17]. Therefore, there is a possibility that the JNK pathway may also be involved in the development of cisplatininduced renal failure at an early stage.

Rao reported that lipopolysaccharide (LPS) induced the production of inflammatory cytokines through ERK
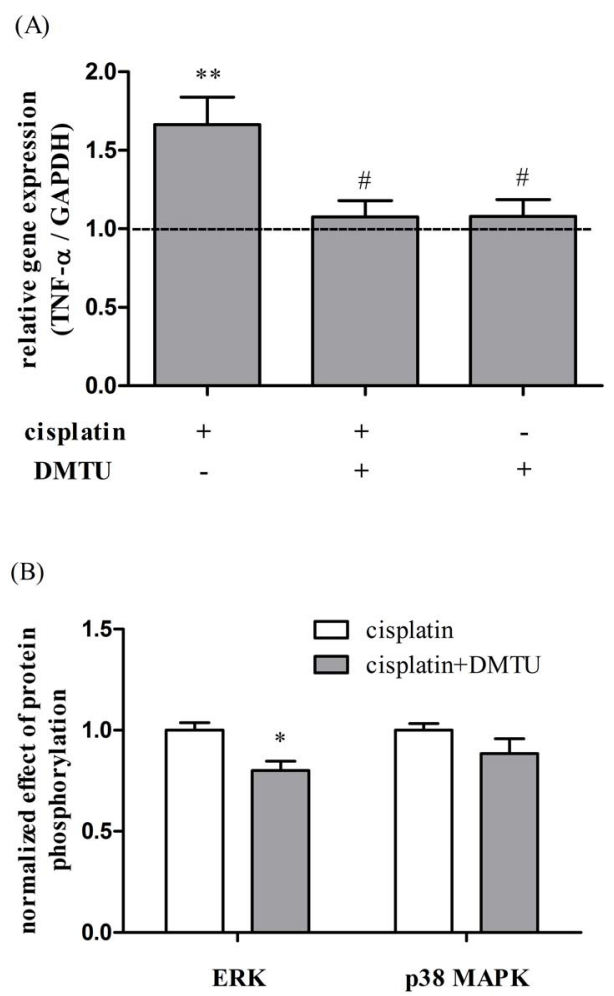

Figure 4. The effects of a radical scavenger on cisplatin-induced TNF- $\alpha$ mRNA expression and MAPK pathway activation. RAW264 cells were treated with $100 \mu M$ DMTU or vehicle between $0.5 \mathrm{~h}$ before and $24 \mathrm{~h}$ after cisplatin $(1 \mu \mathrm{M})$ or vehicle stimulation. TNF- $\alpha$ mRNA expression was then analyzed by RT-PCR (A) and the phosphorylation of ERK and p38 MAPK were analyzed by an ELISA assay kit (B). The mean value of the vehicle control was set to 1.0 (A) and the phosphorylation value in the cisplatin treatment group was set to 1.0 (B). Data are shown as the mean \pm S.E.M. $(n=$ $3-4) .{ }^{* * *} p<0.01$ significantly different from the vehicle control group. ${ }^{\#} p<0.05$ significantly different from the cisplatin group (A). ${ }^{*} p<0.05$ significantly different from the control group (B).

phosphorylation [18]. LPS phosphorylates Ras and Raf-1, upstream-kinases of ERK, and, subsequently, this phosphorylation activates ERK $[19,20]$. The activation of ERK regulates the expression of TNF- $\alpha$ mRNA via the activator protein-1 transcription factor pathway [21-24]. Shishodia reported that cisplatin enhanced the phosphorylation of Ras in macrophages [25]. From these observations, our results indicated that ERK phosphorylation is needed for cisplatin-induced TNF- $\alpha$ mRNA expression in macrophages.

Several studies have shown that ROS leads to increases in the phosphorylation of ERK and p38 MAPK [26-28]. Cisplatin generates hydrogen peroxide $\left(\mathrm{H}_{2} \mathrm{O}_{2}\right)$, a relatively long-lived species of ROS, in a variety of cells including macrophages $[29,30]$. From these findings, we hypothesized that cisplatin-induced TNF- $\alpha$ production in murine macrophages may be due to an increase in ERK 
and 338 MAPK phosphorylation by the $\mathrm{H}_{2} \mathrm{O}_{2}$ generated by cisplatin. We demonstrated that DMTU inhibited the expression of TNF- $\alpha$ mRNA and also decreased cisplatin-induced phosphorylation of ERK. Since DMTU, an agent with a long half-life and the ability to scavenge $\mathrm{H}_{2} \mathrm{O}_{2}$ and hydroxyl radicals selectively, can be highly and rapidly permeable to cell membranes, it has the ability to inhibit the inflammatory response caused by ROS generated within cells [31]. Taken together, ERK activation, induced by $\mathrm{H}_{2} \mathrm{O}_{2}$ and hydroxyl radicals and generated by cisplatin, is essential for the expression of the TNF- $\alpha$ mRNA and production of the TNF- $\alpha$ protein.

We found that although DMTU slightly inhibited the phosphorylation of p38 MAPK, a significant inhibitory effect was not observed (Figure 4). The link between the TNF receptor (TNFR) and p38 MAPK activation has been previously reported $[32,33]$. Ligations of the TNFR phosphorylate MKK3/MKK6, upstream of p38 MAPK, have also been shown $[34,35]$. Therefore, we speculate that autocrine activation by TNF- $\alpha$ caused the phosphorylation of p38 MAPK.

In conclusion, our study showed that macrophages require the ERK pathway for cisplatin-induced TNF- $\alpha$ mRNA expression and that this pathway is phosphorylated by cisplatin-induced ROS.

\section{Acknowledgements}

This study was partially supported by a Grant-in-Aid for scientific research from the Ministry of Education, Science, and Culture of Japan (No. 21590279 and 23790598) and research grants from the Osaka Medical Research Foundation for Incurable Disease and the Osaka Cancer Society.

\section{REFERENCES}

[1] Z. Siddik, "Cisplatin: Mode of Cytotoxic Action and Molecular Basis of Resistance," Oncogene, Vol. 22, 2003, pp. 7265-7279. doi:10.1038/sj.onc.1206933

[2] G. Daugaard and U. Abildgaard, "Cisplatin Nephrotoxicity," Cancer Chemotherapy and Pharmacology, Vol. 25, No. 1, 1989, pp. 1-9. doi:10.1007/BF00694330

[3] K. P. Kang, D. H. Kim, Y. J. Jun, A. S. Lee, S. Lee, S. Y. Lee, K. Y. Jang, M. J. Sung, S. K. Park and W. Kim, "Alpha-Lipoic Acid Attenuates Cisplatin-Induced Acute Kidney Injury in Mice by Suppressing Renal Inflammation," Nephrology Dialysis Transplantation, Vol. 24, No. 10, 2009, pp. 3012-3020. doi:10.1093/ndt/gfp242

[4] L. H. Lu, D. J. Oh, Z. Dursun, Z. He, T. S. Hoke, S. Faubel and C. L. Edelstein, "Increased Macrophage Infiltration and Fractalkine Expression in Cisplatin-Induced Acute Renal Failure in Mice," Journal of Pharmacology and Experimental Therapeutics, Vol. 324, No. 1, 2008, pp. 111-117. doi:10.1124/jpet.107.130161

[5] R. W. Schrier, "Cancer Therapy and Renal Injury," The
Journal of Clinical Investigation, Vol. 110, No. 6, 2002, pp. 743-745. doi:10.1172/JCI16568

[6] G. Ramesh and W. B. Reeves, "p38 MAP Kinase Inhibition Ameliorates Cisplatin Nephrotoxicity in Mice," American Journal of Physiology Renal Physiology, Vol. 289, No. 8, 2005, pp. 166-174. doi:10.1152/ajprenal.00401.2004

[7] N. A. G. Santos, C. S. C. Bezerra, N. M. Martins, C. Curti, M. L. P. Bianchi and A. C. Santos, "Hydroxyl Radical Scavenger Ameliorates Cisplatin-Induced Nephrotoxicity by Preventing Oxidative Stress, Redox State Unbalance, Impairment of Energetic Metabolism and Apoptosis in Rat Kidney Mitochondria," Cancer Chemotherapy and Pharmacology, Vol. 61, No. 1, 2008, pp. 145-155. doi:org/10.1007/s00280-007-0459-y

[8] W. Zhang and H. T. Liu, "MAPK Signal Pathway in the Regulation of Cell Proliferation in Mammalian Cells," Cell Research, Vol. 12, 2002, pp. 9-18.

doi:org/10.1038/sj.cr.7290105

[9] K. L. Cowan and K. B. Storey, "Mitogen-Activated Protein Kinases: New Signaling Pathways Functioning in Cellular Responses to Environmental Stress," The Journal of Experimental Biology, Vol. 206, No. 8, 2003, pp. 1107-1115. doi:org/10.1242/jeb.00220

[10] K. Z. Guyton, M. Gorospe, T. W. Kensler and N. J. Holbrook, "Mitogen-Activated Protein Kinase (MAPK) Activation by Butylated Hydoroxytoluene Hydroperoxide: Implications for Cellular Survival and Tumor Promotion," Cancer Research, Vol. 56, 1996, pp. 3480-3485.

[11] D. W. Hommes, M. P. Peppelenbosch and S. J. H. Deventer, "Mitogen Activated Protein (MAP) Kinase Signal Transduction Pathways and Novel Anti-Inflammatory targets," An International Journal of Gastroenterology and Hepatology, Vol. 29, No. 1, 2003, pp. 144-151. doi:org/10.1136/gut.52.1.144

[12] G. Ramesh, S. R. Kimball, L. S. Jefferson and W. B. Reeves, "Endotoxin and Cisplatin Synergistically Stimulate TNF- $\alpha$ Production by Renal Epithelial Cells," American Journal of Physiology, Vol. 292, No. 2, 2007, pp. 812-819. doi:org/10.1152/ajprenal.00277.2006

[13] B. Zhang, G. Ramesh, S. Uematsu, S. Akira and W. B. Reeves, "TLR4 Signaling Mediates Inflammation and Tissue Injury in Nephrotoxicity," Journal of the American Society of Nephrology, Vol. 19, No. 5, 2008, pp. 923-932. doi:10.1681/ASN.2007090982

[14] T. Suzuki, I. Hide, K. Ido, S. kohsaka, K. Inoue and Y. Nakata, "Production and Release of Neuroprotective Tumor Necrosis Factor by $\mathrm{P} 2 \mathrm{X}_{7}$ Receptor-Activated Microglia," The Journal of Neuroscience, Vol. 24, No. 1, 2004, pp. 1-7. doi:10.1523/JNEUROSCI.3792-03.2004

[15] J. L. Swantek, M. H. Cobb and T. D. Geppert, "Jun N-Terminal Kinase/Stress-Activated Protein Kinase (JNK/ SAPK) Is Required for Lipopolysaccharide Stimulation of Tumor Necrosis Factor Alpha (TNF- $\alpha$ ) Translation: Glucocorticoids Inhibit TNF- $\alpha$ Translation by Blocking JNK/SAPK," Molecular and Cellular Biology, Vol. 17, 1997, pp. 6274-6282.

[16] I. Sánchez-Pérez and R. Perona, "Lack of c-Jun Activity Increases Survival to Cisplatin," FEBS Letters, Vol. 453, 
No. 1-2, 1999, pp. 151-158. doi:10.1016/S0014-5793(99)00690-0

[17] I. Sánchez-Pérez, S. A. Benitah, M. Martínez-Gomariz, J. C. Lacal and R. Perona, "Cell Stress and MEKK1-Mediated c-Jun Activation Modulate NFKB Activity and Cell Viability," Molecular Biology of the Cell, Vol. 13, No. 8, 2002, pp. 2933-2945. doi:10.1091/mbc.E02-01-0022

[18] K. M. Rao, "MAP Kinase Activation in Macrophages," Journal of Leukocyte Biology, Vol. 69, No. 1, 2001, pp. 3-10.

[19] Y. Geng, E. Gulbins, A. Altman and M. Lotz, "Monocyte Deactivation by Interleukin 10 via Inhibition of Tyrosine Kinase Activity and the Ras Signaling Pathway," Proceedings of the National Academy of Sciences of the United States of America, Vol. 91, No. 18, 1994, pp. 8602-8606. doi:10.1073/pnas.91.18.8602

[20] T. Reimann, D. Büscher, R. A. Hipskind, S. Krautwald, M. Lohmann-Matthes and M. Baccarini, "Lipopolysaccharide Induces Activation of the Raf-1/MAP Kinase Pathway," The American Association of Immunologists, Vol. 153, 1994, pp. 5740-5749.

[21] M. S. Lee, Y. J. Kim, "Signaling Pathways Downstream of Pattern-Recognition Receptors and Their Cross Talk," Annual Review of Biochemistry, Vol. 76, 2007, pp. 447480. doi:10.1146/annurev.biochem.76.060605.122847

[22] M. J. Smolinska, T. H. Page, A. M. Urbaniak, B. E. Mutch and N. J. Horwood, "Hck Tyrosine Kinase Regulates TLR4-Induced TNF and IL-6 Production via AP-1," The Journal of Immunology, Vol. 187, No. 11, 2011, pp. 6043-6051. doi:10.4049/jimmunol.1100967

[23] A. B. Carter, M. M. Monick and G. W. Hunninghake, "Both Erk and p38 Kinases Are Necessary for Cytokine Gene Transcription," American Journal of Respiratory Cell and Molecular Biology, Vol. 20, No. 4, 1999, pp. 751-758. doi:10.1165/ajrcmb.20.4.3420

[24] J. A. Frost, T. D. Geppert, M. H. Cobb and J. R. Feramisco, "A Requirement for Extracellular Signal-Regulated Kinase (ERK) Function in the Activation of AP-1 by Ha-Ras, Phorbol 12-Myristate 13-Acetate, and Serum," Proceedings of the National Academy of Sciences of the United States of America, Vol. 91, No. 9, 1994, pp. 3844-3848. doi:10.1073/pnas.91.9.3844

[25] S. Shishodia, A. Sodhi and A. Shrivastava, "Involvement of RAS and MAP Kinase (ERK-1) in Cisplatin-Induced Activation of Murine Bone Marrow-Derived Macrophages," Biochemistry and Molecular Biology International, Vol. 45, 1998, pp. 527-534.

[26] J. Dong, S. Ramachandiran, K. Tikoo, Z. Jia, S. S. Lau and T. J. Monks, "EGFR-Independent Activation of p38 MAPK and EGFR-Dependent Activation of ERK1/2 Are Required for ROS-Induced Renal Cell Death," American
Journal of Physiology Renal Physiology, Vol. 287, No. 5, 2004, pp. 1049-1058. doi:10.1152/ajprenal.00132.2004

[27] A. Sabri and P. A. Lucchesi, "ANG II and Cardiac Myocyte Contractility: p38 Is Not Stressed Out!" American Journal of Physiology Heart and circulatory Physiology, Vol. 290, No. 1, 2006, pp. 72-73.

doi:10.1152/ajpheart.00873.2005

[28] E. M. Galan-Moya, M. A. Cruz-Morcillo, M. L. Valero, J. L. Callejas-Valera, P. Melgar-Rojas, J. H. Losa, M. Salcedo, A. Fernández-Aramburo, S. R. Cajai and R. Sánchezprieto, "Balance between MKK6 and MKK3 Mediates p38 MAPK Associated Resistance to Cisplatin in NDCLC," PLOS ONE, Vol. 6, No. 12, 2011, pp. 1-11. doi:10.1371/journal.pone.0028406

[29] X. Yao, K. Panichpisal, N. Kurtzman and K. Nugent, "Cisplatin Nephrotoxicity: A Review," The American Journal of the Medical Sciences, Vol. 334, No. 2, 2007, pp. 115-124. doi:10.1097/MAJ.0b013e31812dfe1e

[30] C. Runchel, A. Matsuzawa and H. Ichijo, "Mitogen-Activated Protein Kinases in Mammalian Oxidative Stress Responses," Antioxidants and Redox Signaling, Vol. 15, No. 1, 2011, pp. 205-218. doi:10.1089/ars.2010.3733

[31] R. B. Fox, "Prevention of Granulocyte-Mediated Oxidant Lung Injury in Rats by a Hydroxyl Radical Scavenger, Dimethylthiourea," The Journal of Clinical Investigation, Vol. 74, No. 4, 1984, pp. 1456-1464. doi:10.1172/JCI111558

[32] B. Geering, U. Gurzeler, E. Federzoni, T. Kaufmann and H. U. Simon, "A Novel TNFR1-Triggered Apoptosis Pathway Mediated by Class IA PI3Ks in Neutrophils," Blood, Vol. 117, 2011, pp. 5953-5962. doi:10.1182/blood-2010-11-322206

[33] J. Dong, S. Ramachandiran, K. Tikoo, Z. Jia, S. S. Lau and T. J. Monks, "EGFR-Independent Activation of p38 MAPK and EGFR-Dependent Activation of ERK1/2 Are Required for ROS-Induced Renal Cell Death," American Journal of Physiology Renal Physiology, Vol. 29, 2004, pp. 1049-1058.

[34] W. Hove, L. A. Houben, J. A. M. Raaijmakers, M. Bracke and L. Koenderman, "Differential Regulation of TNF $\alpha$ and GM-CSF Induced Activation of P38 MAPK in Neutrophils and Eosinophils," Molecular Immunology, Vol. 44, No. 9, 2007, pp. 2492-2496. doi:10.1016/j.molimm.2006.10.009

[35] K. Suzuki, M. Hino, F. Hato, N. Tatsumi and S. Kitagawa, "Cytokine-Specific Activation of Distinct Mitogen-Activated Protein Kinase Subtype Cascades in Human Neutrophils Stimulated by Granulocyte Colony-Stimulating Factor, Granulocyte-Macrophage Colony-Stimulating Factor, and Tumor Necrosis Factor- $\alpha$," Blood, Vol. 93, 1999, pp. 341-349. 